\title{
UPAYA MENINGKATKAN PEMAHAMAN KONSEP MATEMATIKA DENGAN MODEL PEMBELAJARAN INKUIRI TERBIMBING SISWA KELAS VIII C SMP NEGERI 11 YOGYAKARTA
}

\author{
Agata Sri Sumaryati'), Dwi Uswatun Hasanah') \\ ${ }^{1}$ SMP Negeri 11 Yogyakarta \\ agatasrisumaryati@gmail.com \\ ${ }^{2}$ Pendidikan Matematika FKIP Universitas PGRI Yogyakarta \\ dwiuswatunhasanah@gmail.com
}

\begin{abstract}
ABSTRAK
Penelitian ini bertujuan untuk meningkatkan pemahaman konsep matematika siswa kelas VIII C di SMP Negeri 11 Yogyakarta pada pokok bahasan kubus dan balok dengan model pembelajaran inkuiri terbimbing.

Jenis penelitian ini adalah penelitian tindakan kelas (PTK). Subjek penelitian adalah siswa kelas VIII C SMP Negeri 11 Yogyakarta. Objek penelitian adalah pelaksanaan model pembelajaran inkuiri terbimbing pada pokok bahasan kubus dan balok. Penelitian ini dilaksanakan dalam dua siklus dimana setiap siklus terdiri dari tiga pertemuan. Teknik pengumpulan data menggunakan observasi, wawancara, tes pemahaman konsep, catatan lapangan dan dokumentasi. Teknis analisis data menggunakan teknik kualitatif dan kuantitatif.

Berdasarkan hasil penelitian dapat disimpulkan bahwa pembelajaran matematika dengan model pembelajaran inkuiri terbimbing pada siswa kelas VIII C SMP Negeri 11 Yogyakarta dengan pokok bahasan kubus dan balok dapat: (1) Meningkatkan kemampuan pemahaman konsep matematika siswa yaitu sebelum dilaksanakan tindakan pembelajaran rata-rata nilai siswa sebesar 39,74 dan ketuntasan sebesar 0\% (kategori rendah), setelah dilaksanakan tindakan pembelajaran nilai rata-rata siswa meningkat menjadi 71,62 dan ketuntasan sebesar 55,88\% (kategori cukup) pada siklus I, nilai ratarata siswa meningkat menjadi 85,66 dan ketuntasan sebesar 85,29\% (kategori tinggi) pada siklus II. (2) Keterlaksanaan pembelajaran dilihat dari kegiatan guru sebesar 73,33\% (kategori cukup), kegiatan siswa sebesar 56,47\% (kategori cukup) pada siklus I dan pada siklus II keterlaksanaan pembelajaran dilihat dari kegiatan guru meningkat menjadi 96,67\% (kategori tinggi), kegiatan siswa menjadi 83,71\% (kategori tinggi).
\end{abstract}

Kata kunci : Pemahaman Konsep Matematika, Model Pembelajaran Inkuiri Terbimbing

\section{PENDAHULUAN}

Matematika adalah ilmu abstrak mengenai ruang, bilangan dan studi tentang struktur-struktur abstrak yang memiliki berbagai hubungan dengan ilmu lainnya (Rostina, 2013: 2). Matematika yang bersifat abstrak menyebabkan kesulitan tersendiri yang harus dihadapi oleh siswa untuk mempelajarinya dan guru untuk mengajarkannya kepada siswa. Siswa menganggap matematika sukar dipahami dan menjadi momok yang menakutkan. Ketakutan siswa terhadap matematika membuat siswa menjadi tidak memahami konsep-konsep yang terdapat pada matematika. Pemahaman konsepkonsep yang terdapat dalam matematika sangat diperlukan untuk memahami 
matematika. Konsep-konsep dasar pada matematika harus benar-benar dikuasai sejak awal, sebelum mempelajari matematika lebih lanjut. Dengan memahami konsep terlebih dahulu, siswa akan lebih mudah menerima materi selanjutnya.

Berdasarkan pengamatan yang dilakukan pada pembelajaran matematika di SMP Negeri 11 Yogyakarta di kelas VIII C, peneliti menemukan beberapa hal dalam proses pembelajaran matematika. Pembelajaran di kelas VIII C ini sudah tidak menggunakan cara mengajar guru yang hanya satu arah, namun siswa kurang memahami konsep pembelajaran dan hanya memahami contoh soal serta penyelesainnya sehingga pemahaman konsep matematika siswa menjadi tidak seperti yang diharapkan. Berdasarkan wawancara dengan guru mata pelajaran yang bersangkutan mengatakan bahwa masih banyak siswa yang mendapatkan nilai di bawah KKM. Guru berpendapat bahwa banyaknya siswa yang mendapatkan nilai dibawah KKM disebabkan oleh beberapa faktor yang salah satunya adalah pemahaman konsep siswa masih kurang. Berdasarkan analisi hasil tes pemahaman konsep matematika pra siklus kelas VIII C, kemampuan pemahaman konsep matematika siswa pada tiga indikator pemahaman konsep dengan kategori rendah dan satu indikator dengan kategori cukup. Sedangkan ratarata kemampuan pemahaman konsep matematika siswa memiliki kategori rendah.

Berdasarkan uraian di atas, dibutuhkan suatu model pembelajaran yang mampu membantu siswa agar dapat memahami konsep dasar materi yang dipelajari sehingga tujuan pembelajaran akan tercapai dengan baik. Salah satu model pembelajaran yang dapat membantu siswa agar dapat memahami konsep dasar materi pelajaran adalah model pembelajaran penemuan yang dibimbing oleh guru (inkuiri terbimbing). Model penemuan terbimbing juga lebih menekankan pada aktivitas siswa, siswa mencari dan menemukan jawaban sendiri di bawah bimbingan guru sehingga diharapakan mampu meningkatkan pemahaman konsep matematika siswa.

\section{Rumusan Masalah}

Berdasarkan pembatasan masalah tersebut, maka rumusan masalah dalam penelitian ini adalah "Bagaimanakah model pembelajaran inkuiri terbimbing pada materi kubus dan balok dapat meningkatkan pemahaman konsep matematika siswa kelas VIII C SMP Negeri 11 Yogyakarta?”

\section{Tujuan Penelitian}

Sesuai dengan rumusan masalah yang telah dikemukakan, penelitian ini bertujuan untuk mengetahui model 
Upaya Meningkatkan Pemahaman Konsep Matematika dengan Model Pembelajaran Inkuiri Terbimbing Siswa Kelas VIII C SMP Negeri 11 Yogyakarta

Agata Sri Sumaryati, Dwi Uswatun Hasanah

pembelajaran inkuiri terbimbing dapat model pembelajaran ekspositori. Penelitian meningkatkan pemahaman konsep yang relevan lainnya adalah yang matematika siswa kelas VIII C SMP dilakukan oleh Masta Hutajulu pada tahun Negeri 11 Yogyakarta pada materi kubus 2014 tentang "Meningkatkan Kemampuan dan balok.

Pemahaman Matematik Siswa SMA

\section{Manfaat Hasil Penelitian}

Penelitian ini diharapkan mempunyai beberapa manfaat sebagai berikut:

1. Bagi siswa, diharapkan dapat membantu siswa untuk meningkatkan pemahaman konsep matematika dan menambah pemahaman siswa akan matematika dalam kehidupan seharihari.

2. Bagi guru, diharapkan dapat membantu guru mendapatkan strategi pembelajaran yang tepat dan mempermudah guru dalam memahamkan konsep pembelajaran matematika.

\section{Penelitian yang relevan}

Penelitian yang relevan dengan penelitian ini adalah penelitian yang dilakukan oleh Muhammad Rizqa (2013) tentang perbandingan model pembelajaran inkuiri terbimbing yang menggunakan

\section{LKS (Student Worksheet) Terhadap} Kemampuan Berpikir Abstrak Siswa Kelas X SMA N 1 Bojong". Hasil penelitian peningkatan kemampuan berpikir abstrak siswa pada kelas eksperimen yang menggunakan model pembelajaran inkuiri terbimbing dengan LKS lebih baik dari pada kelas kontrol yang menggunakan
Melalui Model Pembelajaran Inkuiri

Terbimbing”. Hasil penelitian kemampuan pemahaman matematik siswa berdasarkan model pembelajaran inkuiri terbimbing adala 0,6785 . Sedangkan hasil penelitian kemampuan pemahaman matematik siswa berdasarkan model pemebelajaran konvensional adalah 0,4110. Sehingga kelas eksperimen lebih baik dibandingkan kelas kontrol.

\section{KAJIAN TEORI}

\section{Pemahaman Konsep Matematika}

Menurut Paul Eggen dan Don Kauchak (2012: 247-249) pengetahuan siswa dan pemahamannya tentang suatu konsep dapat diukur dengan empat cara, yaitu:

a. Mendefinisikan konsep (A)

b. Mengidentifikasi karakteristikkarakteristik konsep (B)

c. Menghubungkan konsep dengan konsep-konsep lain (C)

d. Mengidentifikasi atau memberikan contoh dari konsep yang belum pernah dijumpai sebelumnya (D)

Model Pembelajaran Inkuiri Terbimbing 
Model inkuiri terbimbing adalah model pembelajaran dimana siswa berpikir sendiri untuk menemukan suatu hasil tertentu yang diharapkan oleh guru yang pelaksanaanya dilakukan oleh siswa dengan berdasarkan pada petunjukpetunjuk yang diberikan oleh guru. Petunjuk yang diberikan oleh guru bersifat pertanyaan-pertanyaan yang membimbing siswa untuk menuju penemuan. Sehingga hasil penemuan tersebut sesuai dengan yang diharapkan oleh guru dan sesuai petunjuk yang diberikan. Adapun tahap pembelajaran inkuiri terbimbing sebagai berikut:

Tabel 1. Tahap Pembelajaran Inkuiri Terbimbing

\begin{tabular}{|c|c|c|}
\hline No & $\begin{array}{c}\text { Tahap } \\
\text { Pembelajara } \\
\mathbf{n}\end{array}$ & Kegiatan \\
\hline 1. & Orientasi & $\begin{array}{l}\text { Guru } \\
\text { mengkondisikan } \\
\text { siswa untuk memulai } \\
\text { pembelajaran, } \\
\text { menyampaikan } \\
\text { tujuan pembelajaran } \\
\text { dan memotivasi } \\
\text { siswa }\end{array}$ \\
\hline 2. & $\begin{array}{l}\text { Merumuskan } \\
\text { masalah }\end{array}$ & $\begin{array}{l}\text { Guru memberikan } \\
\text { permasalahan atau } \\
\text { persoalan yang } \\
\text { mengandung teka- } \\
\text { teki dan konsep yang } \\
\text { jelas dan mengajak } \\
\text { siswa untuk } \\
\text { mengidentifikasi } \\
\text { masalah tersebut }\end{array}$ \\
\hline 3. & $\begin{array}{c}\text { Merumuskan } \\
\text { hipotesis }\end{array}$ & $\begin{array}{l}\text { Guru mendorong } \\
\text { siswa untuk } \\
\text { merumuskan } \\
\text { jawaban sementara } \\
\text { Permasalahan yang } \\
\text { sedang dikaji }\end{array}$ \\
\hline 4. & $\begin{array}{l}\text { Mengumpul } \\
\text { kan data }\end{array}$ & $\begin{array}{l}\text { Siswa mendiskusikan } \\
\text { penyelesaian } \\
\text { pertanyaan- } \\
\text { pertanyaan yang } \\
\text { diberikan guru } \\
\text { melalui LKS dengan } \\
\text { kelompoknya }\end{array}$ \\
\hline 5. & $\begin{array}{l}\text { Menguji } \\
\text { hipotesis }\end{array}$ & $\begin{array}{l}\text { Guru membimbing } \\
\text { siswa untuk } \\
\text { menentukan jawaban } \\
\text { berdasarkan hasil } \\
\text { pengumpulan data }\end{array}$ \\
\hline 6. & $\begin{array}{l}\text { Merumuskan } \\
\text { kesimpulan }\end{array}$ & $\begin{array}{l}\text { Guru membimbing } \\
\text { siswa untuk } \\
\text { menyimpulkan dan } \\
\text { jawaban men } \\
\text { menemukan konsep }\end{array}$ \\
\hline
\end{tabular}

Menurut Hamruni (2012: 100-101) menyebutkan beberapa kelebihan model pembelajaran inkuiri terbimbing diantaranya:

1) Menekankan kepada pengembangan aspek kognitif, afektif, dan psikomotor secara seimbang, sehingga pembelajaran dianggap lebih bermakna.

2) Memberikan kesempatan kepada siswa untuk belajar sesuai dengan gaya belajarnya.

3) Sesuai dengan perkembangan psikologi belajar modern yang menganggap belajar adalah proses perubahan tingkah laku melalui pengalaman.

4) Mampu melayani kebutuhan siswa yang memiliki kemampuan di atas rata-rata, sehingga siswa yang memiliki kemampuan belajar bagus tidak akan terhambat oleh siswa yang lemah dalam belajar.

Sedangkan kelemahan model pembelajaran inkuiri terbimbing menurut Hamruni (2012: 101) adalah sebagai berikut:

1) Sulit mengontrol kegiatan dan keberhasilan siswa.

2) Tidak mudah merencanakan pembelajaran, karena terbentur pada kebiasaan siswa.

3) Implementasinya memerlukan waktu yang panjang, sehingga guru sulit 
Upaya Meningkatkan Pemahaman Konsep Matematika dengan Model Pembelajaran Inkuiri Terbimbing Siswa Kelas VIII C SMP Negeri 11 Yogyakarta Agata Sri Sumaryati, Dwi Uswatun Hasanah

menyesuaikan dengan waktu yang Keterangan:

telah ditentukan.

\section{METODE PENELITIAN}

Jenis penelitian yang digunakan adalah penelitian tindakan kelas (PTK) atau Classroom Action Reseach (CAR) yang dilakukan secara kolaboratif dan partisifatif. Variabel bebas dalam penelitian ini yaitu penggunaan model pembelajaran inkuiri terbimbing pada pokok bahasan kubus dan balok. Variabel terikat dalam penelitian ini adalah pemahaman konsep matematika. Subjek dalam penelitian ini adalah siswa kelas VIII C SMP Negeri 11 Yogyakarta. Objek dalam penelitian ini adalah penerapan model pembelajaran inkuiri terbimbing pada materi kubus dan balok untuk siswa kelas VIII C SMP Negeri 11 Yogyakarta. Prosedur penelitian yang digunakan pada penelitian adalah sebagai berikut (Wijaya Kusuma dan Dedi Dwitagama, 2010: 21):

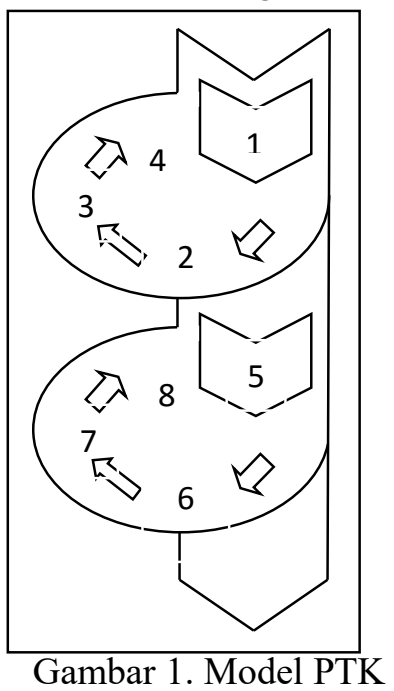

1. Perencanaan (Planning)

2. Pelaksananan Tindakan (Acting)

3. Pengamatan (Observing)

4. Refleksi (Reflecting)

5. Perbaikan Perencanaan (Revised Planning)

6. Pelaksanaan Tindakan (Acting)

7. Pengamatan (Observing)

8. Refleksi (Reflecting)

Konsep pokok penelitian tindakan menurut Kemmis dan Mc Taggart dapat mencakup beberapa siklus dan pada masing-masing siklus terdiri dari empat komponen yaitu:

1. Perencanaan (planning)

2. Pelaksanaan (action)

3. Pengamatan (observing)

4. Refleksi (reflecting)

Empat langkah utama yang saling berkaitan ini disebut sebagai satu siklus. Penelitian ini dirancang dalam dua siklus yang setiap siklusnya terdiri dari 3 pertemuan. Teknik pengumpulan data dalam penelitian ini dikumpulkan melalui observasi, wawancara, tes pemahaman konsep, catatan lapangan, dan dokumentasi. Teknik analisis data pada penelitian ini dengan dua metode pengumpulan data yaitu metode kualitatif dan kuantitatif. Analisis data kualitatif digunakan untuk peningkatan proses belajar, sedangkan analisis data kuantitatif digunakan untuk menentukan pemahaman konsep matematika siswa. Siklus dihentikan apabila ada peningkatan 
pemahaman konsep matematika siswa. Hal tersebut ditunjukkan dengan meningkatnya persentase nilai tes pemahaman konsep pada setiap siklus dengan kategori tinggi yaitu minimal $75 \%$.

\section{HASIL DAN PEMBAHASAN}

Hasil ini menunjukkan bahwa keterlaksanaan pemebelajaran mengalami peningkatan. Adapun grafik peningkatan keterlaksanaan pembelejaran adalah sebagai berikut:

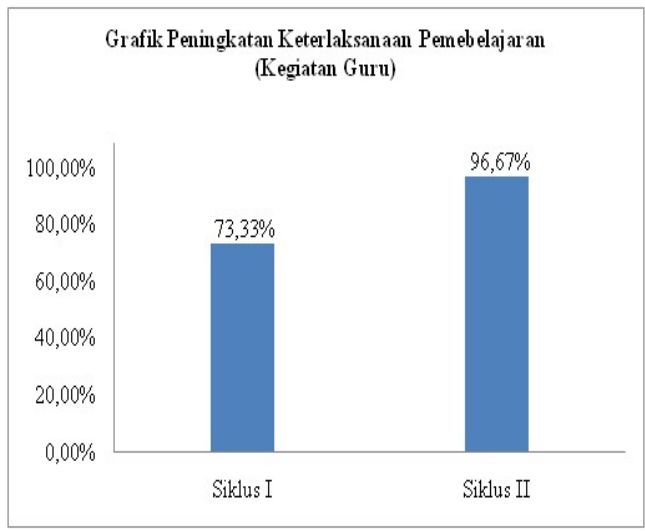

Gambar 2. Grafik Peningkatan Keterlaksanaan Pembelajaran Kegiatan Guru dengan Model Inkuiri Terbimbing

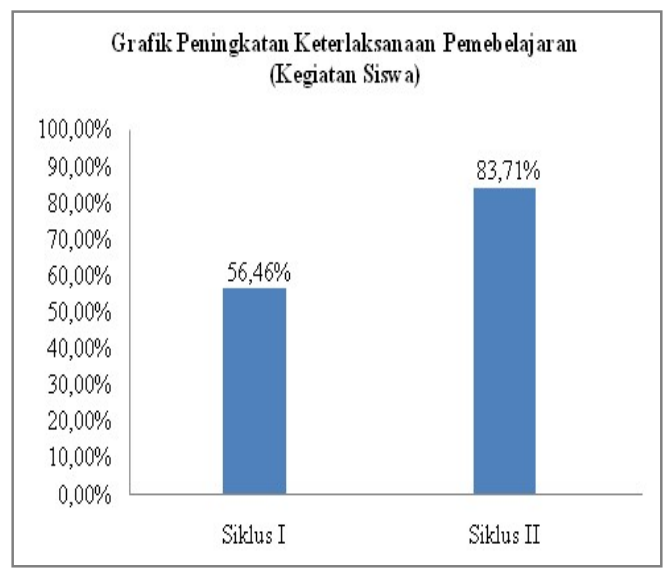

Gambar 3. Grafik Peningkatan

Keterlaksanaan Pembelajaran Kegiatan Siswa dengan Model Inkuiri Terbimbing

\section{1) Peningkatan Pemahaman Konsep Matematika Secara Klasikal}

Pada akhir siklus diadakan tes pemahaman konsep matematika. Pada tes awal yang diberikan sebelum tindakan diperoleh rata-rata nilai kemampuan pemahaman konsep matematika siswa kelas VIII C adalah 39,74 dengan tidak ada siswa yang mencapai ketuntasan. Pada tes pemahaman konsep matematika 1 diperoleh nilai rata-rata kemampuan pemahaman konsep matematika adalah 71,62 dengan 19 siswa yang mencapai ketuntasan. Rata-rata nilai kemampuan pemahaman konsep matematika sudah meningkat. Ketuntasan siswa masih belum seperti yang diharapkan peneliti, maka dilakukan siklus II untuk memperbaiki siklus sebelumnya. Pada tes pemahaman konsep matematika 2 diperoleh nilai ratarata kemampuan pemahaman konsep matematika adalah 85,66 dengan 29 siswa yang mencapai ketuntasan. Nilai rata-rata kemampuan pemahaman konsep matematika sudah meningkat dan sesuai dengan harapan peneliti. Hasil tes pemahaman konsep matematika dengan peningkatan rata-rata nilai pemahaman konsep matematika secara klasikal dan ketuntasan siswa dalam bentuk grafik berikut: 
Upaya Meningkatkan Pemahaman Konsep Matematika dengan Model Pembelajaran Inkuiri Terbimbing Siswa Kelas VIII C SMP Negeri 11 Yogyakarta Agata Sri Sumaryati, Dwi Uswatun Hasanah

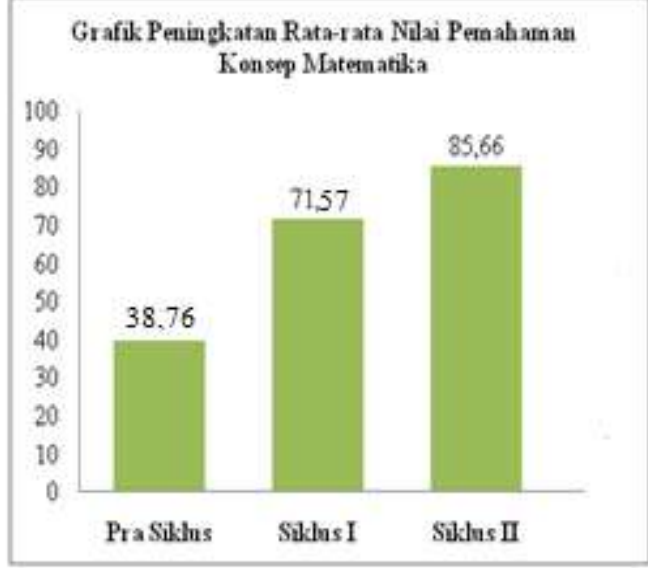

Gambar 4. Grafik Peningkatan Rata-rata Nilai Pemahaman Konsep Metematika Siswa

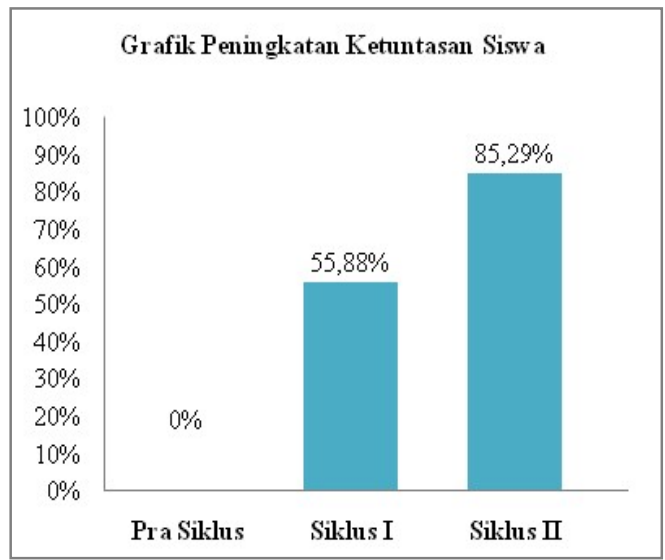

Gambar 5. Grafik Peningkatan Ketuntasan Siswa

Berdasarkan uraian di atas, dapat dikatakan bahwa proses pembelajaran yang menggunakan model pembelajaran inkuiri terbimbing dapat meningkatkan pemahaman konsep matematika siswa.

\section{2) Peningkatan Kemampuan Pemahaman Konsep Matematika Berdasarkan Indikator Pemahaman Konsep}

Hasil tes pemahaman konsep matematika ditinjau dari setiap indikator pemahaman konsep sebelum penelitian dan setelah penelitian yang dilaksanakan siklus

I dan siklus II disajikan sebagai berikut:

Tabel 2. Hasil Tes Pemahaman Konsep

Matematika Setiap Indikator pada Pra Siklus, Siklus I dan Siklus II

\begin{tabular}{|c|c|c|c|c|}
\hline \multirow{2}{*}{\multicolumn{2}{|c|}{$\begin{array}{l}\text { Indikator } \\
\text { Pemahaman } \\
\text { Konsep }\end{array}$}} & \multicolumn{3}{|c|}{$\begin{array}{c}\text { Hasil Tes Pemahaman } \\
\text { Konsep Matematika }\end{array}$} \\
\hline & & \begin{tabular}{|c|} 
Pra \\
Siklus \\
\end{tabular} & $\begin{array}{c}\text { Siklus } \\
\text { I }\end{array}$ & \multirow{2}{*}{\begin{tabular}{|c|}
$\begin{array}{c}\text { Siklus } \\
\text { II }\end{array}$ \\
$\begin{array}{c}76,96 \\
\%\end{array}$
\end{tabular}} \\
\hline A & $\begin{array}{l}\text { Mendefinis } \\
\text { ikan konsep }\end{array}$ & $28,43 \%$ & $\begin{array}{c}70,59 \\
\%\end{array}$ & \\
\hline B & $\begin{array}{l}\text { Mengidenti } \\
\text { fikasi } \\
\text { karakteristi } \\
\text { k- } \\
\text { karakteristi } \\
\text { k konsep }\end{array}$ & $31,96 \%$ & $\begin{array}{c}74,35 \\
\%\end{array}$ & $\begin{array}{c}99,02 \\
\%\end{array}$ \\
\hline $\mathrm{C}$ & $\begin{array}{l}\text { Menghubu } \\
\text { ngkan } \\
\text { konsep } \\
\text { dengan } \\
\text { konsep- } \\
\text { konsep lain }\end{array}$ & $31,37 \%$ & $\begin{array}{c}61,62 \\
\%\end{array}$ & $\begin{array}{c}83,58 \\
\%\end{array}$ \\
\hline D & $\begin{array}{l}\text { Mengidenti } \\
\text { fikasi atau } \\
\text { memberika } \\
\text { n contoh } \\
\text { dari konsep } \\
\text { yang belum } \\
\text { pernah } \\
\text { dijumpai } \\
\text { sebelumnya }\end{array}$ & $63,40 \%$ & $\begin{array}{c}85,29 \\
\%\end{array}$ & $\begin{array}{c}97,06 \\
\%\end{array}$ \\
\hline & $\begin{array}{l}\text { Rata-Rata } \\
\text { Pemahaman } \\
\text { Konsep } \\
\text { Matematika }\end{array}$ & $38,79 \%$ & $\begin{array}{c}72,96 \\
\%\end{array}$ & $\begin{array}{c}89,15 \\
\%\end{array}$ \\
\hline & Kategori & Rendah & Cukup & Tinggi \\
\hline
\end{tabular}

Hasil tes pemahaman konsep matematika dilihat dari setiap indikator pemahaman konsep sebelum penelitian dan setelah penelitian yang dilaksanakan siklus I dan siklus II diperjelas dengan grafik berikut: 


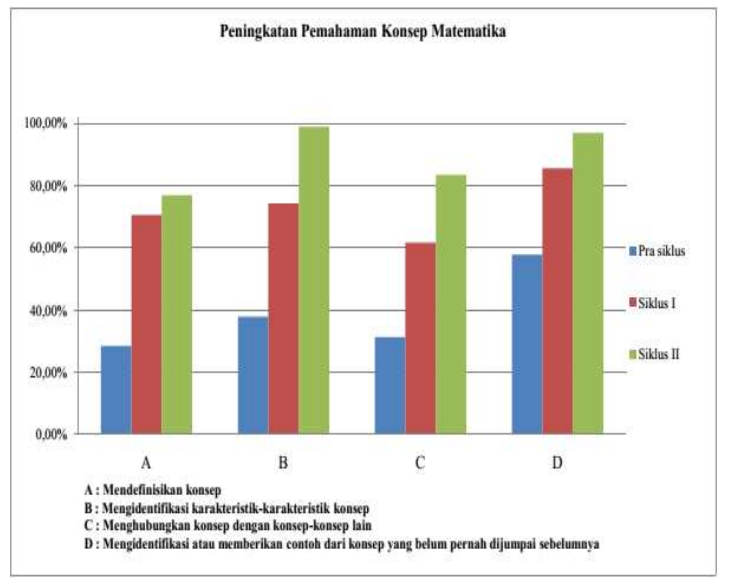

Gambar 6. Grafik Peningkatan Pemahaman Konsep Metematika Setiap Indikator

\section{KESIMPULAN}

Berdasarkan hasil Penelitian Tindakan Kelas (PTK) yang dilakukan secara kolaboratif antara peneliti dengan guru mata pelajaran matematika kelas VIII C SMP Negeri 11 Yogyakarta, penerapan model pembelajaran inkuiri terbimbing pada materi kubus dan balok dapat terlaksana dengan baik sesuai dengan tahap-tahap pembelajaran inkuiri terbimbing. Hal ini terlihat dari keterlaksanaan pembelajaran kegiatan guru dan siswa pada setiap siklus mengalami peningkatan. Rata-rata persentase keterlaksanaan pembelajaran kegiatan guru sebesar sebesar 73,33\% (kategori cukup), kegiatan siswa sebesar 56,47\% (kategori cukup) pada siklus I dan pada siklus II rata-rata persentase keterlaksanaan pembelajaran kegiatan guru meningkat menjadi 96,67\% (kategori tinggi), kegiatan siswa sebesar $83,71 \%$ (kategori tinggi).
Penggunaan model pembelajaran inkuiri terbimbing dalam pembelajaran matematika pada materi kubus dan balok dapat meningkatkan kemampuan pemahaman konsep matematika siswa kelas VIII C SMP Negeri 11 Yogyakarta. Kemampuan pemahaman konsep matematika siswa meningkat dari rata-rata nilai kemampuan pemahaman konsep matematika sebelum tindakan pembelajaran dengan model pembelajaran inkuiri terbimbing sebesar 38,76 dan ketuntasan sebesar 0\% (kategori sangat rendah), pada siklus I rata-rata nilai kemampuan pemahaman konsep matematika meningkat menjadi 71,57 dan ketuntasan sebesar $55,88 \%$ (kategori cukup), dan pada siklus II rata-rata nilai kemampuan pemahaman konsep matematika meningkat menjadi 85,66 dan ketuntasan sebesar 85,29 \% (kategori tinggi). Dapat disimpulkan bahwa kemampuan pemahaman konsep matematika siswa mengalami peningkatan sebesar 45,55 dan ketuntasan siswa mengalami peningkatan sebesar $85,29 \%$.

\section{REFERENSI}

Eggen, Paul dan Don Kauchak. 2012. Strategi dan Model Pembelajaran. Jakarta: Indeks.

Hamruni. 2012. Strategi Pembelajaran.. Yogyakarta: Insan Madani.

Masta Hutajulu. 2014. Meningkatkan Kemampuan Pemahaman 
Upaya Meningkatkan Pemahaman Konsep Matematika dengan Model Pembelajaran Inkuiri Terbimbing Siswa Kelas VIII C SMP Negeri 11 Yogyakarta

Agata Sri Sumaryati, Dwi Uswatun Hasanah

Matematik Siswa SMA Melalui

Model Pembelajaran Inkuiri

Terbimbing dalam Prosiding

Seminar Nasional Pendidikan

Matematika 2014 Volume 1 (ISSN

2355-0473) halaman 82 diterbitkan

tanggal 15 januari 2014

http://publikasi.stkipsiliwangi.ac.id

/files/2014/01/Prosiding-15-

Januari-2014.pdf diunduh pada 25

Oktober 2014.

Muhammad Rizqa. 2013. Efektivitas Model

Pembelajaran Inkuiri Terbimbing

(Guided Inquiry) Menggunakan

Lembar Kerja Siswa (Student

Worksheet) Terhadap Kemampuan

Berpikir Abstrak Siswa Kelas X

SMA N 1 Bojong Tahun 2012/2013

http://library.ikippgrismg.ac.id/doc

files/fulltext/6d1e732082a2a615.pd

f diunduh pada 25 Oktober 2014.

Rostina Sundayana. 2013. Media

Pembelajaran Matematika.

Bandung: Alfabeta.

Wijaya K dan Dedi D. 2010. Mengenal

Penelitian Tindakan Kelas. Jakarta:

PT. Indeks. 